\title{
PENGGUNAAN PERANGKAT LUNAK BERLISENSI PUBLIK SEBAGAI TRADISI SEHAT BERBUDAYA
}

\author{
Oleh \\ Putu Hendra Suputra, \\ Jurusan Manajemen Informatika, FTK, UNDIKSHA
}

\begin{abstract}
ABSTRAK
Penggunaan komputer di Indonesia sangat pesat, terlebih pada masa masyarakat informasi, namun perkembangan ini tidak didukung oleh peningkatan kesadaran akan penggunaan software secara legal. Penggunaan software secara ilegal tidak hanya bertentangan dengan hukum, namun memperburuk iklim investasi di mata dunia, serta menunjukkan ketidakmampuan pemerintah dalam menegakkan supremasi hukum dan apresiasi HAKI. Terdapat beberapa ulasan dan pertimbangan dalam memperbaiki citra negatif ini sekaligus membenahi sistem pendidikan TIK di Indonesia, secara paralel, dan memperhatikan beberapa faktor, karena penggunaan software bajakan di Indonesia telah menjadi tradisi yang sulit dihilangkan. Diperlukan upaya strategis jangka panjang dan berkesinambungan untuk mengikis budaya buruk sekaligus meningkatkan efisiensi dan daya saing sumber daya manusia Indonesia terhadap produk software luar negeri, dengan tetap berpihak pada kepentingan masyarakat. Ulasan ditekankan pada peningkatan kesadaran akan penggunaan software secara legal, perubahan paradigma pendidikan TIK, serta memupuk rasa keterbukaan atas perubahan yang baik.
\end{abstract}

Kata kunci: software ilegal, migrasi, bajakan, sistem operasi, TIK, opensource, HKI/HAKI

\begin{abstract}
The use of computers in Indonesia grows rapidly especially in the information society. Unfortunately, This positive progres is not followed by awareness of the use of software legally. The use of illegal software not only unlawful, but also worsen the investment climate in Indonesia and shows the government incapability in upholding the rule of law and appreciation of intelectual property (IPR). There are several reviews and study in order to minimalize this negative impact of it. The ICT education system should be fixed. Counter piracy must consider several factors in parallel, because the use of pirated software in Indonesia has become a tradition that is hard to remove. It takes a long-term strategic effort to erode this negative culture and to improve efficiency and competitiveness of Indonesia's human resources software products abroad. This study gave emphasis on increasing awareness of the use of software legally, change the paradigm of ICT education, and foster a sense of openness for change.
\end{abstract}

Keywords: illegal software, software migration, piracy, operating system, ICT, opensource, IP/IPR 


\section{LATAR BELAKANG}

Penggunaan teknologi komputer dan informasi semakin berkembang dan mau tidak mau arus teknologi ini turut mempengaruhi pola kerja di berbagai bidang. Sebagian menyambut era komputerisasi dengan antusias, namun tidak sedikit yang mengalami kendala dalam pemanfaatannya, baik dari sisi perangkat keras maupun perangkat lunak. Beruntung banyak pelatihan dan kursus yang membantu menyelesaikan kendala ini. Dengan semakin mudah dan murahnya perangkat komputer, penetrasi teknologi komputer dan internet sudah tidak menjadi sebuah euforia.

Sebagai negara yang sudah melewati era masyarakat terkomputerisasi, Indonesia merupakan pengguna teknologi komputer yang cukup besar di asia pasifik. Semakin mudah dan murahnya perangkat komputer dan internet hingga ke pelosok daerah memperkuat penetrasi teknologi ini sampai ke pedesaan. Pengguna komputer juga semakin beragam dari berbagai tingkatan sosial pekerjaan, begitu pula dari rentang usia yang kian hari kian meluas. Fenomena tersebut merupakan perkembangan positif bagi pertumbuhan ekonomi mikro maupun perluasan informasi pada masyarakat.

Pertumbuhan penggunaan teknologi komputer yang pesat ternyata tidak diiringi dengan kesadaran akan penggunaan perangkat lunak (software) yang legal. Indonesia saat ini masih berada dalam peringkat teratas Negara pengguna perangkat lunak illegal. Ini salah satu penyebab yang membuat citra Indonesia menjadi yang kurang baik di mata dunia. Berdasarkan survei International Data Corporation (IDC)tahun 2007, Indonesia berada pada urutan ke-12 dari 108 negara dengan angka penggunaan perangkat lunak ilegal mencapai $84 \%$. Angka ini menunjukan perbaikan dibandingkan dengan tahun sebelumnya, yakni pada tahun 2006 yang mencapai 85\%. Meski demikian, dari sisi peringkat justru turun. Kalau pada 2006 Indonesia menempati peringkat ke-8, tahun 2007 Justru turun menempati posisi ke-12 (Prihatman, 2010).

Business Software Alliance (BSA) merilis data tentang pembajakan software yang menyebutkan bahwa lima puluh tiga persen software yang ter-install di asia pasifik merupakan sistem bajakan pada tahun 2003. Jumlah tersebut setara dengan 
kerugian US\$ 7,5 milar. Asia pasifik - Indonesia termasuk di dalamnya - adalah wilayah dengan tingkat pembajakan software tertinggi keempat dan kerugian peringkat kedua di seluruh dunia.

Kasus pembajakan perangkat lunak di Indonesia tidak cukup ditangani dengan perangkat hukum. Pembajakan perangkat lunak sudah seperti tradisi di masyarakat karena telah berlangsung lama. Perlu upaya pengikisan kebiasaan dan edukasi terhadap masyarakat secara menyeluruh agar penegakan aturan dapat dilaksanakan, serta memperbaiki citra dan kepercayaan masyarakat terhadap pengelolaan pemerintahan.

\section{PEMBAHASAN}

\subsection{Sistem operasi}

Antarmuka komputer yang dianggap baik adalah antarmuka yang ramah pengguna. Komputer yang ramah pengguna (user friendly) menjadi faktor pertimbangan utama dalam pemilihan sistem yang akan digunakan. Pada kenyataannya masyarakat tidak memiliki pilihan terhadap sistem yang akan mereka gunakan. Hal tersebut bukan karena hanya ada satu sistem saja, melainkan karena masyarakat belum teredukasi tentang sistem yang menjadi landasan (platform) dalam kegiatan berkomputer. Terdapat banyak pilihan sistem operasi yang dapat digunakan, mulai dari yang berlisensi publik maupun proprietary.

Saat ini bangsa Indonesia telah memasuki masa masyarakat sistem informasi, di mana penggunaan sistem berbasis komputer telah menjadi urat nadi transfer informasi yang utama. Kita boleh bangga atas pesatnya adaptasi bangsa Indonesia dalam menyerap teknologi informasi sekaligus menghasilkan tenaga-tenaga handal di bidang ini. Komputer bahkan telah diperkenalkan sejak dini kepada siswa sejak usia muda. Tidak dapat dipungkiri bahwa keahlian komputer menjadi salah satu syarat wajib ketika mencari pekerjaan. Hampir setiap pengguna komputer mampu mengoperasikan sistem operasi buatan Microsoft yang memang memiliki fitur dan antarmuka yang ramah pengguna. Sebagian besar perangkat komputer yang ada terinstal software yang sifatnya berbayar, namun digunakan secara ilegal. Software bajakan (ilegal) masih mendominasi sebagian besar komputer tersebut. 
Pengguna komputer baik dengan sadar maupun tanpa sadar telah menggunakan sistem operasi dan perangkat lunak ilegal. Pengguna awam tidak memiliki kesempatan untuk memilih perangkat lunak, bukan karena tidak mau, melainkan karena sistem dan lingkungan yang tidak mendukung penggunaan perangkat lunak yang legal.

Penggunaan perangkat lunak adalah sah saja sepanjang tidak melanggar hukum dan ketentuan berlaku. Penggunaan produk berbayar tanpa membayar tentu saja merupakan suatu kegiatan ilegal. Pengguna komputer saat ini dengan sadar ataupun tanpa sadar telah menggunakan perangkat lunak ilegal. Sistem operasi yang populer saat ini yaitu Microsoft Windows menawarkan antarmuka yang ramah pengguna dan memiliki fitur yang menarik, sehingga mayoritas pengguna menggunakannya. Aplikasi perkantoran buatan Microsoft yaitu Microsoft Office juga sangat luas digunakan, tidak hanya karena fitur yang ditawarkan, tetapi karena masyarakat pengguna yang tidak terbuka atas perubahan.

\subsection{Penggunaan software ilegal menjadi budaya}

Kebudayaan dipandang sebagai sesuatu yang turun-temurun dari satu generasi ke generasi yang lain, di mana di dalamnya terkandung nilai sosial, norma sosial, ilmu pengetahuan, serta struktur sosial, dan lain-lain. Penggunaan komputer telah menjadi bagian budaya manusia. Namun secara mengejutkan, khususnya di Indonesia, penggunaan perangkat lunak ilegal yang sewajarnya bertentangan dengan norma dan aturan, justru mendapatkan permakluman dan pembiaran. Kesan ini muncul bahkan dari pemerintah dan aparat terkait atas beberapa petimbangan. Apa yang menjadi pertimbangan dapat dikaji pada studi yang lain. Fenomena ini berlangsung sejak lama sehingga sedikit demi sedikit menjadi budaya atau tradisi.

Menghilangkan suatu tradisi tidak mudah dan tidak cukup dengan hukum. Penegakan hukum pada kondisi seperti ini dapat menimbulkan gejolak di masyarakat, terlebih jika masyarakat belum siap melakukan perubahan. Penegakan hukum yang lemah dapat menurunkan tingkat kepercayaan publik terhadap pemerinthan yang berjlaan. Namun pada kasus seperti ini, penerapan hukum di lapangan tidak serta merta berjalan tanpa hambatan. Tindakan pertama yang harus dilakukan adalah mengikis budaya atau tradisi negatif dengan tindakan-tindakan 
taktis yang menyentuh langsung akar permasalahan. Tradisi menggunakan perangkat lunak ilegal tidak muncul dengan sendirinya. Penggunaan software ilegal terlalu lama dimaklumi sehingga menjadi budaya dan merevisi nilai norma masyarakat atas pelanggaran hak orang lain. Sebagai suatu bentuk pelanggaran, penyalahgunaan hak cipta tentu telah disadari oleh penegak hukum dan pemerintah, dan disadari pula bahwa sebagian besar sistem yang beredar adalah perangkat lunak ilegal, sehingga tidak mungkin dilakukan razia secara keseluruhan, dengan kata lain razia dilakukan dengan pilah-pilih - yang berpotensi menimbulkan kecemburuan sosial.

\subsection{Memberi kesempatan untuk menggunakan software legal}

Komputer sangat membantu meningkatkan produktivitas pekerjaan di segala bidang, sehingga pemerintah pada masanya turut mengakselerasi pemanfaatan perangkat komputer dalam menunjang kegiatan termasuk di dalam institusi pemerintahan sendiri. Sistem pendidikan juga beberapa kali mengalami revisi dan perkembangan khususnya dalam mempersiapkan siswa untuk tanggap terhadap perkembangan teknologi informasi dan komunikasi (TIK). Namun sayangnya pendidikan TIK masih belum dikenalkan tentang legalitas atau lisensi suatu produk. Pengenalan komputer tidak memberikan alternatif pilihan sistem operasi kepada siswa, melainkan pemberian keterampilan menggunakan perangkat lunak tertentu yang ironisnya masih bajakan. Sebagai mata pelajaran yang relatif baru, tentu saja tenaga pengajar yang ada belum mencukupi atau belum dipersiapkan secara matang untuk memberikan pendidikan TIK secara matang dari aspek teknis (keterampilan) dan aspek sosialnya.

Salah satu akar masalah berkembangnya software bajakan adalah faktor sumber daya pemakai software itu sendiri. Siswa sejak dini diperkenalkan tentang komputer. Titik awal inilah yang memegang peranan penting, karena dari pembiasaan akan berlanjut ke jenjang berikutnya. Pendidikan TIK selanyaknya memberi kebebasan pada siswa untuk memilih sistem operasi komputer. Alasan tenaga pendidik yang belum siap tidak dapat diterima, karena secara logika tenaga pendidik harus mampu menjalankan fungsinya sesuai dengan kurikulum. Kurikulum pendidikan TIK untuk siswa tidak boleh berdasarkan pada produk tertentu yang 
pada akhirnya memaksa siswa dan guru untuk menggunakan produk tertentu, sama kondisinya dengan larangan guru untuk menggunakan buku pelajaran tertentu (terlebih menjual) kepada siswa. Kurikulum TIK sebaiknya berpegang pada penanaman konsep menggunakan komputer, bukan menggunakan software tertentu. Perkembangan komputer sangat pesat, sehingga pelatihan keterampilan pada software tertentu hanya akan menyesatkan siswa karena mengesampingkan faktor kreativitas dan penalaran dalam menggunakan komputer.

Dalam proses belajar mengajar, khususnya di jenjang yang lebih tinggi (perguruan tinggi), tanpa disadari dosen dan penyelenggara pendidikan memaksa mahasiswa dan dosen untuk menggunakan software bajakan. Sebagai contoh, ketika dosen memberikan tugas, biasanya mengharuskan mahasiswa untuk mengumpulkan dalam format file tertentu.

\subsection{Memberi contoh yang baik}

Salah satu cara untuk menanamkan pemahaman tentang legalitas software adalah dengan berkaca pada diri sendiri dan memberikan contoh yang baik. Pemerintah dalam peranannya membina masyarakat seharusnya memberikan teladan dengan menata dan membenahi institusi-institusi pemerintahan untuk menggunakan komputer secara legal, termasuk meningkatkan keterampilan pegawai agar mampu menggunakan perangkat dengan baik tanpa melanggar hak cipta. Banyak sistem dan software yang tersedia, namun pegawai tidak memiliki keterampilan yang memadai, sehingga kembali lagi pada sistem pendidikan TIK yang perlu dibenahi.

Perubahan peraturan dan kebijakan di bidang pendidikan tidak selaras dengan niat pemerintah untuk go open source. Penuntasan pembajakan software harus dilakukan secara paralel karena melibatkan banyak faktor. Program go open source tidak didukung oleh perbaikan kurikulum pendidikan TIK di sekolah. Program ini juga tidak dijalankan secara riil di lingkungan pemerintahan secara berkesinambungan. Perlu alokasi APBN yang memadai untuk riset dan sosialisasi penggunaan software legal ataupun open source.

\subsection{Pembajakan mematikan kreativitas}

Industri perangkat lunak dewasa ini merupakan salah satu bidang penting yang mampu memberikan andil dalam memperkuat ekonomi bangsa Indonesia. 
Industri perangkat lunak tidak saja menyangkut aspek ekonomi, namun juga mencerminkan kreativitas dan kemampuan sumber daya manusia di Indonesia. Semakin tinggi penggunaan perangkat lunak buatan dalam negri, mencerminkan tingkat kepercayaan bangsa terhadap kemampuan diri sendiri, sehingga pada akhirnya dapat meningkatkan daya saing terhadap produk luar.

Penggunaan software bajakan yang umumnya produk luar negri menunjukkan rendahnya kepercayaan diri masyarakat kita dalam menggunakan alternatif lain terutama buatan dalam negeri. Prihatman (2010) mengemukakan dampak yang terasa terhadap adanya isu negatif ini adalah dari sisi investasi. Investor menjadi kurang tertarik untuk berinvestasi di Indonesia dan peluang negara ini untuk menjadi salah satu tujuan investasi dunia pun berkurang. Upaya perbaikan citra sebagai Negara pengguna perangkat lunak legal yang masuk peringkat dunia yang akan mengakibatkan perbaikan iklim investasi di Indonesia.

Berbagai upaya telah dilakukan untuk memperbaiki citra ini, salah satunya dengan membentuk Tim Nasional Penanggulangan Pelanggaran Hak Atas Kekayaan Intelektual (Timnas HAKI) berdasarkan Keputusan Presiden No. 4/2006 yang tugas utamanya adalah menanggulangi pelanggaran HAKI dengan menentukan kebijakan nasional dan langkah-langkah strategis yang dibutuhkan dalam penegakan HAKI (Prihatman, 2010). Namun upaya hukum tanpa pertimbangan sosial budaya akan sia-sia saja mengingat karakteristik permasalahan tidak berada pada ranah hukum saja.

\subsection{Penuntasan software ilegal}

Usaha penuntasan masalah penggunaan software ilegal di Indonesia sudah menjadi salah satu program pemerintah khususnya lembaga penegakan hukum. Tindakan represif seperti razia terhadap penggunaan software ilegal sering dilakukan, sampai pemeriksaan laptop di bandara sempat digelar. Namun dalam perjalanannya, usaha penegakan Indonesia sepertinya tidak mampu mempertahankan taji dan menunjukkan kewibawaanya. Kemunduran seperti ini bukan kali ini saja terjadi, penyebabnya bukan karena tidak adanya aturan perundangundangan. Jika ditelaah dari beberapa sisi, ternyata tindak pelanggaran hak cipta yang marak terjadi di tanah air memiliki kompleksitas yang tidak cukup 
dipandang dari sisi hukum. Penegakan hukum terhadap pelanggaran atas hak atas kekayaan intelektual memang sepantasnya ditegakkan. Namun dinamika di lapangan memunculkan dilema yang efeknya luas.

Pemerintah selayaknya bersikap bijaksana terhadap kasus penegakan hak atas kekayaan intelektual, dengan tetap berpihak pada kepentingan masyarakat. Penanganan terhadap kasus ini harus dilakukan secara bijaksana dan dipandang dari beberapa perspektif yang berbeda, terlebih masyarakat pengguna komputer di Indonesia masih belum sepenuhnya siap berbenah diri menggunakan komputer secara legal. Penuntasan penggunaan software secara ilegal di Indonesia tidak hanya menyentuh ranah hukum, namun sudah menjadi bagian dari ranah sosial yang kompleks dan mungkin sensitif. Jadi sebelum menerapkan pasal-pasal hukum, perlu ditemukan akar permasalahan sosialnya agar tidak menimbulkan gejolak di masyarakat.

Amandemen terhadap undang-undang yang berkaitan dengan hak cipta tentu saja diharapkan dengan melihat aspirasi yang berkembang di masyarakat demi penyempurnaan penegakan hukum di Indonesia, dengan catatan tetap membela kepentingan masyarakat.

Edukasi terhadap masyarakat perlu dilakukan secara konsisten agar sedikit demi sedikit dapat memberikan pemahaman kepada publik. Edukasi juga diberikan untuk meningkatkan daya saing dan inovasi di Indonesia. Persaingan dan inovasi akan menciptakan atmosfer bisnis yang positif khususnya pada bidang pengembangan industri informasi dan komunikasi yang sesuai dengan kebutuhan di Indonesia.

\subsection{Terbuka terhadap perubahan}

Spesifikasi komputer yang digunakan untuk bekerja seharusnya dsesuaikan dengan sifat dan karakteristik peruntukan komputer tersebut. Namun dalam membeli komputer, banyak kemampuan (fitur) yang dimiliki komputer dirasa berlebihan termasuk dalam pemilihan software di dalamnya. Fitur dan fasilitas berlebihan pada dasarnya adalah pemborosan, karena setiap fitur pasti memiliki harga yang harus dibayarkan. Pengguna komputer harus paham sistem seperti apa yang sesuai dengan pekerjaannya. Namun dengan mudahnya software bajakan yang beredar, pengguna 
tidak perlu pusing mempertimbangkan pemilihan software, karena merasa tidak mengeluarkan biaya apapun untuk memperoleh software-software tambahan tersebut - yang kemungkinan besar tidak diperlukan.

Pada sistem operasi opensource, software yang dapat digunakan sangat beragam dan sebagian besar merupakan software gratis karena didukung oleh komunitas opensource. Ada beberapa alasan yang dapat dijadikan dasar untuk melirik upaya migrasi ke opensource sebagai platform utama (Prihatman, 2010) antara lain:

A) Kemandirian. Pemilihan perangkat lunak open source menjadi pengguna memiliki akses terhadap sumber kode, sehingga memberikan fleksibilitas dan kebebasan kepada pengguna individu atau instansi. Pengguna dapat memilih, mengganti dan mengembangkan paket perangkat lunak, berganti platform atau vendor yang berbeda dengan tanpa menimbulkan masalah.

B) Kesempatan mengejar ketertinggalan. Dengan sifatnya yang memiliki sumber kode terbuka, ini mengakibatkan para pengembang lokal (Indonesia) dapat lebih cepat dalam mengembangkan aplikasi yang disesuaikan dengan kebutuhan pengguna. Dampak dari pengembangan perangkat lunak opensource ini adalah percepatan kesempatan penyediaan lapangan kerja bagi tanaga ahli teknologi informasi (TI) yang dapat menyumbang kepada Produk Domestik Bruto (PDB) secara signifikan.

C) Untuk kondisi Indonesia, kelebihan opensource adalah adanya penghematan biaya bagi para pengguna. Komponen biaya yang dapat dihemat, antara lain, biaya bayar lisensi perangkat lunak, biaya yang harus keluar karena gangguan virus, biaya yang harus dikeluarkan ketika data hilang karena kesalahan program disistem atau biaya paket perangkat lunak, up-grade dan service. Dari sisi biaya lisensi saja dapat dibayangkan berapa biaya yang dapat dihemat apabila diterapkan dalam jumlah jutaan computer.

D) berbagai alasan teknis, seperti skalabilitas penggunaan opensource kini sudah sangat meluas, kinerja opensource yang mampu berjalan dengan normal di mesin dengan kemampuan rendah, kehandalan yang dimiliki system operasi ini sudah tidak diragukan lagi, maupun keamanan sistem di 
mana opensource merupakan system yang terbuka, maka sangat kecil kemungkinan untuk dimasuki program yang dapat merusak sistem .

\section{PENUTUP}

Penuntasan penggunaan perangkat lunak secara ilegal di Indonesia tidak cukup dengan perangkat hukum yang membatasi ruang gerak dan menindak pelaku pembajakan. Kasus yang terjadi di Indonesia harus dipandang dari beberapa perspektif berbeda karena permasalahan tidak berada dalam ranah hukum, melainkan juga sosial, budaya, dan ekonomi. Pemerintah dan sistem pendidikan di Indonesia memiliki andil dalam teerbentuknya budaya bajak-membajak software di tanah air, dan sudah berlangsung sangat lama sehingga mengakar seolah menjadi budaya bangsa ini. Tentu saja kesan tersebut menjadi sentimen negatif terhadap iklim investasi dan pandangan dunia terhadap bangsa Indonesia yang berpengaruh terhadap daya saing dan kewibawaan pemerintah dalam menegakkan supremasi hukum di Indonesia. Salah satu akar permasalahan yang harus diselesaikan terlebih dahulu adalah kurikulum pendidikan TIK yang saat ini kurang memperhatikan aspek legalitas, di samping itu pola pengajarannya masih berorientasi pada keterampilan menggunakan software, sehingga aspek keilmuan dan penalaran kurang ditanamkan.

\section{DAFTAR PUSTAKA}

Anonim, 2007, Piracy Study, Fourth Annual BSA and IDC Global Software, BSA\&IDC.

Dhani Gartina, 2009, Penggunaan Software Open Source dalam Mendukung Kegiatan Penelitian dan Administrasi Perkantoran, Informatika Pertanian Volume 18 No.1, www.litbang.deptan.go.id/warta-ip (diakses tanggal 6 Mei 2011)

Prihatman Kemal, 2010, Penegakan Software Legal dengan Migrasi ke OSS, http://www.ristek.go.id/, (diakses tanggal 26 Januari 2011) 